\title{
Comparison of microscopic method and computational program for pesticide deposition evaluation of spraying(1)
}

\author{
Aldemir Chaim ${ }^{(2)}$, Maria Conceição Peres Young Pessoa( ${ }^{(2)}$, João Camargo Neto ${ }^{(3)}$ and Luiz Carlos Hermes ${ }^{(2)}$
}

\begin{abstract}
The main objective of this work was to compare two methods to estimate the deposition of pesticide applied by aerial spraying. Hundred and fifty pieces of water sensitive paper were distributed over an area of $50 \mathrm{~m}$ length by $75 \mathrm{~m}$ width for sampling droplets sprayed by an aircraft calibrated to apply a spray volume of $32 \mathrm{~L} / \mathrm{ha}$. The samples were analysed by visual microscopic method using NG 2 Porton graticule and by an image analyser computer program. The results reached by visual microscopic method were the following: volume median diameter, $398 \pm 62 \mu \mathrm{m}$; number median diameter, $159 \pm 22 \mu \mathrm{m}$; droplet density, $22.5 \pm 7.0$ droplets $/ \mathrm{cm}^{2}$ and estimated deposited volume, $22.2 \pm 9.4 \mathrm{~L} / \mathrm{ha}$. The respective ones reached with the computer program were: $402 \pm 58 \mu \mathrm{m}, 161 \pm 32 \mu \mathrm{m}, 21.9 \pm 7.5$ droplets $/ \mathrm{cm}^{2}$ and $21.9 \pm 9.2 \mathrm{~L} / \mathrm{ha}$. Graphs of the spatial distribution of droplet density and deposited spray volume on the area were produced by the computer program.
\end{abstract}

Index terms: agricultural chemicals, aerial application, application methods, density, volume.

\section{Comparação de método microscópico e programa computacional para a estimativa da deposição de agrotóxicos pela pulverização aérea}

\begin{abstract}
Resumo - O principal objetivo deste trabalho foi comparar dois métodos para estimar a deposição de agrotóxicos aplicados por pulverização aérea. Foram distribuídos 150 cartões sensíveis à água numa área de $50 \mathrm{~m}$ de comprimento por $75 \mathrm{~m}$ de largura, para amostrar gotas pulverizadas por uma aeronave calibrada para aplicar um volume de calda de $32 \mathrm{~L} / \mathrm{ha}$. As amostras foram analisadas pelo método de visualização microscópica com a utilização de uma gratícula de Porton NG 2 e por um programa de computador analisador de imagens. Os resultados obtidos pelo método de visualização microscópica foram: diâmetro mediano volumétrico, $398 \pm 62 \mu \mathrm{m}$; diâmetro mediano numérico, $159 \pm 22 \mu \mathrm{m}$; densidade de gotas, 22,5 $\pm 7,0$ gotas $/ \mathrm{cm}^{2}$ e volume depositado estimado, 22,2 $\pm 9,4 \mathrm{~L} / \mathrm{ha}$. Os respectivos resultados obtidos pelo programa de computador foram: $402 \pm 58 \mu \mathrm{m}, 161 \pm 32 \mu \mathrm{m}, 21,9 \pm 7,5 \mathrm{gotas} / \mathrm{cm}^{2} \mathrm{e}$ $21,9 \pm 9,2 \mathrm{~L} / \mathrm{ha}$. O programa de computador possibilitou a produção de gráficos com a distribuição espacial da densidade de gotas e volumes depositados na área da aplicação.
\end{abstract}

Termos para indexação: produtos agroquímicos, aplicação aérea, métodos de aplicação, densidade, volume.

\section{Introduction}

Pesticide applications have been described as a very inefficient process and the quantity of the

\footnotetext{
(1) Accepted for publication on July 11, 2001

(2) Embrapa-Centro Nacional de Pesquisa de Monitoramento e Avaliação de Impacto Ambiental, Caixa Postal 69, CEP 13820-000 Jaguariúna, SP. E-mail: aldemir@cnpma.embrapa.br young@cnpma.embrapa.br, hermes@cnpma.embrapa.br

(3) Embrapa-Centro Nacional de Pesquisa Tecnológica em Informática para Agricultura, Caixa Postal 6041, CEP 13083-970 Campinas, SP
}

chemicals that really reaches the target is lower than that applied (Chaim et al., 1999a, 1999d). The available methods for analysis of the pesticide deposition are either sophisticated or expensive, for that reason, new alternatives are tried (Franz, 1993; Derksen \& Jiang, 1995; Jiang \& Derksen, 1995).

Aerial deposition can be determined either by measuring the chemical residue on the crop and soil surfaces or only by collecting the deposit on artificial targets, like water sensitive paper (Chaim et al., 1999c). Since artificial targets are not efficient as most natural substrates in trapping aerial deposits, they 
can give only an estimate of the deposition on the natural substrates. Natural substrates are most difficult to sampling, as well as residue analysis due to the elevate cost, laborious and time consuming, and results that do not readily show the deposit patterns (Chaim et al., 1999a, 1999c).

Chaim et al. (1999c) proposed a method to evaluate the spray volume deposited on water sensitive paper that considers the medium volume and droplet density. Pessoa \& Chaim (1999) developed a computer program that uses a polynomial interpolation to obtain the volume median diameter and number median diameter, and an empirical model calculates the respective spread factor to correct the stains to true droplet diameters for samples. The mathematical equation developed by Chaim et al. (1999b, 1999c) was also included in the program for estimating the volume deposited on the target. After that first computational approach a new computer program was developed to take in account a module for image analysis, for automatic droplet counting.

The objective of this work was to compare results reached by a visual microscopic method and the new computer program for pesticide deposition analysis.

\section{Material and Methods}

The water sensitive papers, a Ciba-Geigy product (distributed exclusively by Spraying System Company), with 76 by $26 \mathrm{~mm}$, were mounted on glass slides (100 by $50 \mathrm{~mm}$ ) using $19 \mathrm{~mm}$-wide double stick tape. A total of 150 samples set up on clay bricks were distributed over an area of $50 \mathrm{~m}$ of length by $75 \mathrm{~m}$ width. These artificial targets were distributed in a halfway form $(5 \times 5 \mathrm{~m})$, in a screen formed by 10 lines with 15 sampling units each (Figure 1).

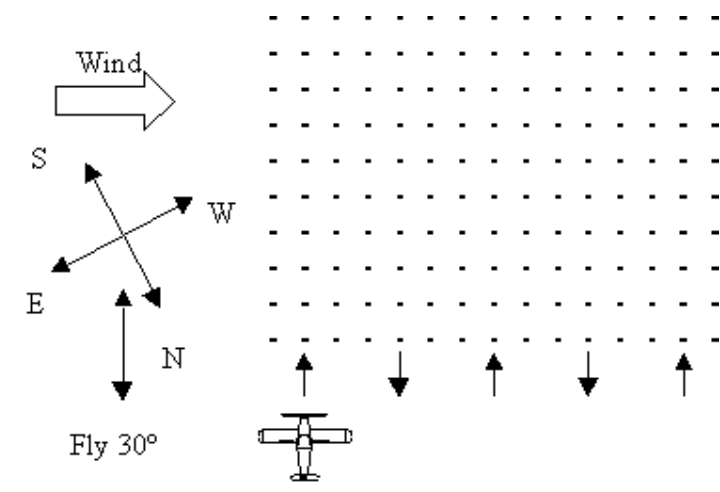

Figure 1. Spatial distribution of samples on an area with $50 \mathrm{~m}$ of length and $75 \mathrm{~m}$ of width.
The field spraying was made with an Ipanema EMB 201-A aircraft equipped with boom with 26 hollow cone nozzles (D8-46) oriented $135^{\circ}$ to the rear. The pressure was $207 \mathrm{kPa}$ and the aircraft flew at $170 \mathrm{~km} / \mathrm{h}$ at $3 \mathrm{~m}$ height to produce a swath $15 \mathrm{~m}$ wide. The resulting spray volume was $32 \mathrm{~L} / \mathrm{ha}$.

Temperature, relative humidity and wind velocity were monitored by a ventilated psychrometer and a cup anemometer coupled in a Campbell Scientific $21 \mathrm{X}$ Micrologger.

For the microscopic method, the size classifications of the droplet stains were carried out with Porton NG 2 graticule coupled in microscope eyepiece, according to the method described by Chaim et al. (1999c). Data of droplet size classification and its density for the 150 samples were organized as an input file of the computer program previously developed by Pessoa \& Chaim (1999), to reach volume median diameter, number median diameter and estimated deposited volume of spray.

The images of the 150 water sensitive paper pieces were captured by a 600 dpi resolution scanner and used as input for the new computer program for pesticide deposition analysis method. The new software was developed in PASCAL language, based on the preliminary version proposed by Pessoa \& Chaim (1999) using the formula developed by Chaim et al. (1999c, 1999d) to estimate the spray volume deposited on water sensitive paper. A polynomial interpolation algorithm was used to reach the volume median diameter and number median diameter and an empirical model to calculate the respective spread factor for different droplet sizes, to correct the stains to true droplet diameters. The inverse distance square weighting interpolation method was used to produce graphs of the spatial distribution of droplet densities and volume of spray deposited on field test area.

\section{Results and Discussion}

The meteorological parameters observed during the period of spraying were as follow: wind speed, $1,0 \mathrm{~m} / \mathrm{s}$; relative humidity, $70 \%$; and temperature, $17^{\circ} \mathrm{C}$. Those conditions could be considered as excellent for reduction of drift and of droplets evaporation.

The time spent for counting and size classification around 300 droplets by sample using the microscopic method was 15 minutes or approximately 38 hours for all samples. This method has been very laborious and tiresome for the operator. The same number of samples analysed by de new program spent five hours, including the time for image scanning. 
The resolution of the computer program for droplet size classification was $47.78 \mu \mathrm{m} /$ pixel and the minimum stain diameter sized by microscopic method was $67 \mu \mathrm{m}$.

The $\mathrm{F}$ ratio obtained by analysis of variance (ANOVA) demonstrated that the visual microscopic method and computer program presented very similar results for volume median diameter, number median diameter, droplet density and volume (Table 1). For visual microscopic classification of droplet stains, comparisons between the computer program and the log probability paper method for volume median diameter and number median diameter estimation showed differences around just $1 \%$ (Pessoa \& Chaim, 1999).

Previous work showed that the volume estimated by droplet counting and sizing presented a good correlation with chemical tracer analyser method (Chaim et al., 1999c). However the precision of the estimated volume by droplet counting and sizing depends on the quality of the classification of the stains.

As the calculation of volume median diameter, number median diameter and estimated deposited volume was the same for both methods, the major difference between them was the visual microscopic and automatic image analysis for counting and sizing the droplet stains. The new computer method allows an additional information about the percentage of the area covered by the droplets stains. This information is important in the cases of high intensity of deposition of droplets, when a separation of the stains is impossible.

The great variability of droplet density obtained for both methods presented in Table 1 can be ex- plained in Figure 1. A simple mean analysis of the results presented in Table 1, would not be better tool to improve the spraying calibration. However, Figure 1 obtained by new computer method shows that apparently the densities between 17 and 31 droplets $/ \mathrm{cm}^{2}$ was close to the flying strip positioning and covering $66.56 \%$ of the total sprayed area. This non-uniform pattern of droplet density deposition was probably caused by the aircraft turbulence and so could explain the data variability.

The great variability of estimated deposited volume was also explained by Figure 2 . Volumes between 2 and $24 \mathrm{~L} /$ ha were deposited on $69.99 \%$ of the sprayed area, however, high volumes were deposited in very small areas and that deposition phenomenon can not be explained by a simple analysis of the average and standard deviations presented in Table 1 . The pattern of volume distribution presented by Figure 2 showed that this problem needs to be corrected by the choice of a new spraying calibration.

In spite of the graph in Figure 2 to show some coincident areas with those presented in Figure 3, the pattern of spatial distribution of the droplet density was different from that of the deposited volume. The different spatial distribution patterns showed in Figures 2 and 3 emphasize the need to change the actual method used for aerial spraying calibration, that is based only on droplet size and its deposition density.

So the new computer program is a good tool for farmers, engineers or other professionals that work with pesticide application and with little or no access to the use of chemical tracer methods for sprayer calibration.

Table 1. Results of droplet analysis, its standard deviation and the F ratio for ANOVA attained by both the visual microscopic and computer methods, for aerial spraying of $32 \mathrm{~L} / \mathrm{ha}$ of water.

\begin{tabular}{lccc}
\hline Parameters estimated & $\begin{array}{c}\text { Visual microscopic } \\
(\mathrm{A})\end{array}$ & $\begin{array}{c}\text { Computer } \\
(\mathrm{B})\end{array}$ & $\begin{array}{c}\text { F ratio for comparison } \\
\text { of A and B }\end{array}$ \\
\hline Volume median diameter $(\mu \mathrm{m})$ & $398 \pm 62$ & $402 \pm 58$ & $0.27^{\mathrm{ns}}$ \\
Number median diameter $(\mu \mathrm{m})$ & $159 \pm 22$ & $161 \pm 32$ & $0.36^{\mathrm{ns}}$ \\
Density $\left(\right.$ droplets $\left./ \mathrm{cm}^{2}\right)$ & $22.5 \pm 7.0$ & $21.9 \pm 7.5$ & $0.12^{\text {ns }}$ \\
Deposited volume $(\mathrm{L} / \mathrm{ha})$ & $22.2 \pm 9.4$ & $21.9 \pm 9.2$ & $0.24^{\mathrm{ns}}$ \\
Target area coverage $(\%)$ & - & $3.9 \pm 1.5$ & - \\
\hline
\end{tabular}

${ }^{n}$ Non-significant at $1 \%$ level of probability by the $\mathrm{F}$ test. 


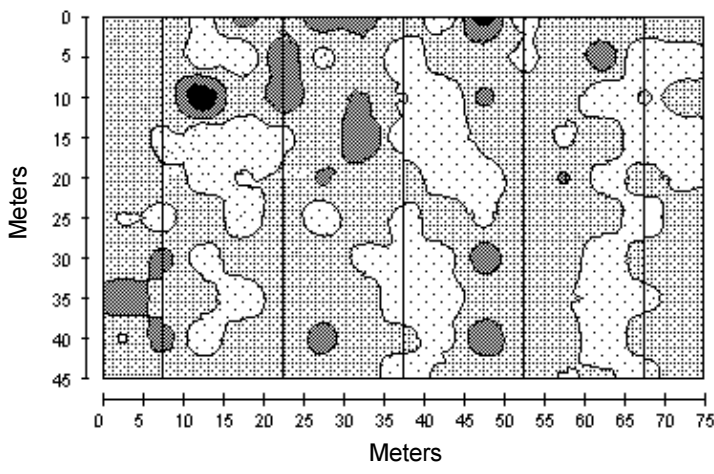

$0.34 \%=45-60$ droplets $/ \mathrm{cm}^{2}$ $6.17 \%=31-45$ droplets $/ \mathrm{cm}^{2}$ $64.94 \%=17-31$ droplets $/ \mathrm{cm}^{2}$ $28.54 \%=3-17$ droplets $/ \mathrm{cm}^{2}$

Figure 2. Spatial distribution (\%) of droplet density $\left(\mathrm{n} \% / \mathrm{cm}^{2}\right)$. The vertical lines indicate aircraft flight path.

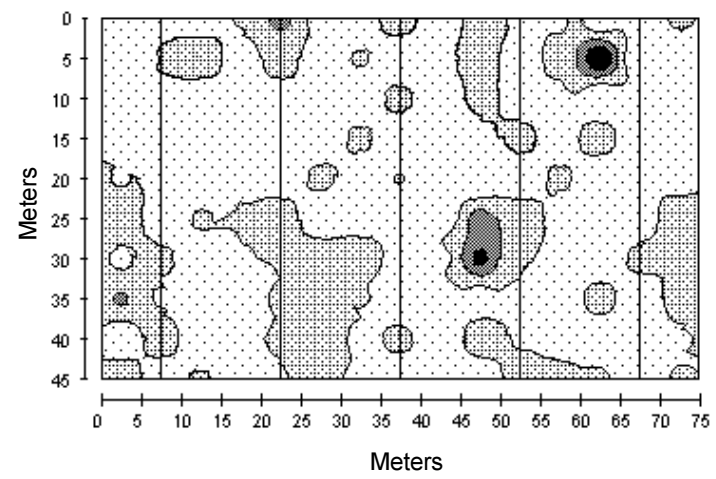

$0.36 \%=68-90 \mathrm{~L} / \mathrm{ha} \quad 1.50 \%=46-68 \mathrm{~L} / \mathrm{ha}$ $28.96 \%=24-46 \mathrm{~L} / \mathrm{ha} \quad 69.20 \%=2-24 \mathrm{~L} / \mathrm{ha}$

Figure 3. Spatial distribution (\%) of estimated deposited volume (L/ha). The vertical lines indicate aircraft flight path.

\section{Conclusions}

1. The visual microscopic method and computer program give similar results for volume median diameter, number median diameter, droplet density and deposited estimated volume.
2. The time spent with microscopic method is greater than that consumed by the computer program.

3 . The computer program produces graphs with the spatial distribution droplet density and deposited estimated volume.

\section{References}

CHAIM, A.; CASTRO, V. L. S. S.; CORRALES, M. C.; GALVÃO, J. A. H.; CABRAL, O. M. R.; NICOLELLA, G. Método para monitorar perdas de agrotóxicos na cultura do tomate. Pesquisa Agropecuária Brasileira, Brasília, v. 34, n. 5, p. 741-747, maio 1999a.

CHAIM, A.; MAIA, A. H. N.; PESSOA, M. C. P. Y. Estimativa de deposição de agrotóxicos por análise de gotas. Pesquisa Agropecuária Brasileira, Brasília, v. 34, n. 6, p. 963-969, jun. 1999b.

CHAIM, A.; MAIA, A. H. N.; PESSOA, M. C. P. Y.; HERMES, L. C. Método alternativo para estimar deposição de agrotóxico com uso de papel sensível a água. Jaguariúna: Embrapa-CNPMA, 1999c. 34 p. (Circular Técnica, 1).

CHAIM, A.; VALARINI, P. J.; OLIVEIRA, D. A.; MORSOLETO, R. V.; PIO, L. C. Avaliação de perdas de pulverização nas culturas de feijão e tomate. Jaguariúna: Embrapa-CNPMA, 1999d. 29 p. (Boletim de Pesquisa, 2)

DERKSEN, R. C.; JIANG, C. Automated detection of fluorescent spray deposits with a computer vision system. Transactions of the ASAE, Saint Joseph, v. 38, n. 6, p. 1647-1653, 1995 .

FRANZ, E. Spray coverage analysis using a hand-held scanner. Transactions of the ASAE, Saint Joseph, v. 36, n. 5, p. 1271-1278, 1993.

JIANG, G.; DERKSEN, R. C. Morphological image processing for spray deposit analysis. Transactions of the ASAE, Saint Joseph, v. 38, n. 5, p. 1581-1591, 1995.

PESSOA, M. C. P. Y.; CHAIM, A. Programa computacional para estimativa de uniformidade de gotas de herbicidas aplicados por pulverização aérea. Pesquisa Agropecuária Brasileira, Brasília, v. 34, n. 1, p. 45-56, jan. 1999. 